\title{
ROLE OF CELEBRITY ENDORSEMENT IN MAKING A SOCIAL CAMPAIGN SUCCESSFUL WITH SPECIAL REFERENCE TO JAIPUR CITY
}

\author{
Dr. Ujjvala M. Tiwari ${ }^{1 \square}$ (D), Bhakti Bakshi ${ }^{2 \square}$ (iD) \\ Associate Professor IIS Deemed University, Jaipur, India \\ ${ }^{2}$ Research Scholar IIS Deemed University, Jaipur, India
}

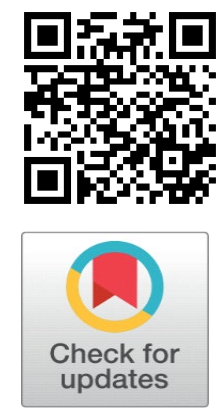

Received 07 December 2021

Accepted 21 February 2022

Published 04 March 2022

\section{CorrespondingAuthor \\ Bhakti Bakshi, \\ bhakti.bakshi@jecrcu.edu.in \\ DOI}

10.29121/shodhkosh.v3.i1.2022.79

Funding: This research received no specific grant from any funding agency in the public, commercial, or not-for-profit sectors.

Copyright: (C) 2022 The Author(s). This is an open access article distributed under the terms of the Creative Commons Attribution License, which permits unrestricted use, distribution, and reproduction in any medium, provided the original author and source are credited.

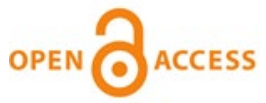

\section{ABSTRACT}

A celebrity is said to be any individual who is famous amongst the public and this recognition of him is used to promote products or sometimes messages that are in public interest or even a social message making it a Social Advertisement. Social advertisements are one that give the viewer some serious thought about the social issue with the primary purpose of it being to educate the masses through the messages that are harder hitting that could help in the positive change. Celebrity endorsement is widely used as a tool to create awareness about any social problem like smoking, pulse polio, drugs, alcohol, domestic violence, population, pollution, family planning, care and concern for the old age or disabled, National Integration, rape, health, and cleanliness etc. and not just promoting ideas of Greater Awareness of social norms but also leads to better understanding and better solution to the societal problems.

Keywords: Social Advertisement, National Integration, Promotional Objective

\section{INTRODUCTION}

Celebrities generally have an influence on the lives of people, it is seen that people get influenced by them and try following their favourite one's. Celebrities have that factor of influencing as the people know them and can relate or connect with them. In the recent years a trend of using celebrities for number of brands in India has been noticed using a celebrity as an endorser the promotional objective of the campaign has to be looked into and it is made sure that the celebrities image matches with the promotional objective this trend of celebrity endorsement has a very well outcome in social advertising as using celebrity to get public attention makes it easy to grab viewers' attention as people easily connect with them, and are inspired by them the viewers are the biggest admirers of these celebrities and want to live like them, follow them, their lifestyle and habits. Sela (2016)

A lot of successful campaigns have been done by India's most famous celebrities which have a high impact on public, one of the most successful campaigns on social issues which presents honorable Prime Minister for The Swachh Bharat Abhiyan which was initiated by him on the $2^{\text {nd of }}$ October 2014 naming it The Cleanliness Campaign, he ambitiously picked up the broom to clean the

According to one of the reports by The Economic Times Jaipur is one of the cities which can be regarded as the showpiece achievers of Swachh Bharat Abhiyan and also under the Narendra Modi award list suggestions. The state 
Capital Jaipur has come a long way within a year form the times when the garbage was not properly disposed to the times of having proper door to door waste collection system and a more proper disposal and treatment of the waste, Jaipur today treats its waste and convert it to composite and to Refuse Derived Fuel, RDF and is now planning to set up a waste to energy plant at Languriyawas which would treat 600 metric tonnes of garbage to energy. Jaipur has also built 1588 individual household toilets 600 community toilets and 300 urinals under this Swachh Bharat Abhiyan. The Economic Times, Politics (2018)

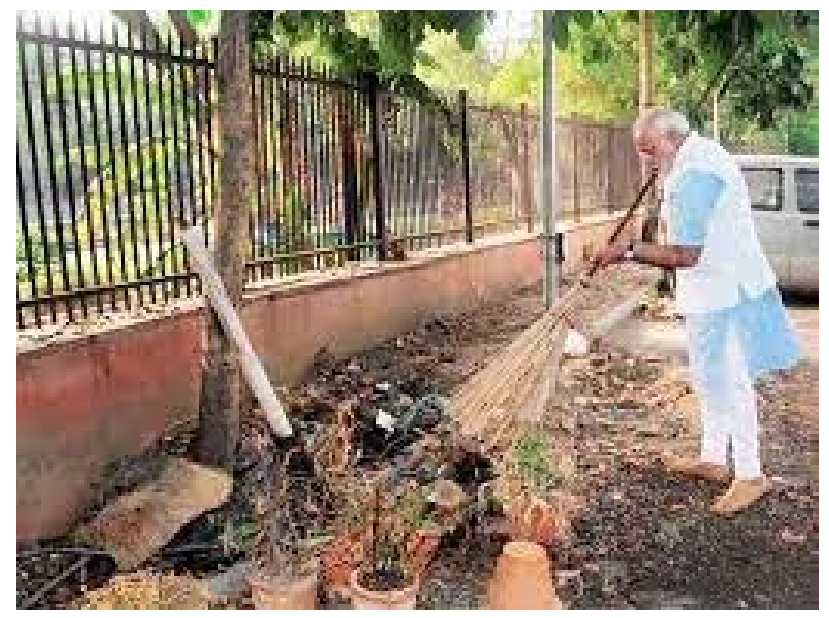

Figure 1 PM Narendra Modi initiating The Swachh Bharat Abhiyan

Source

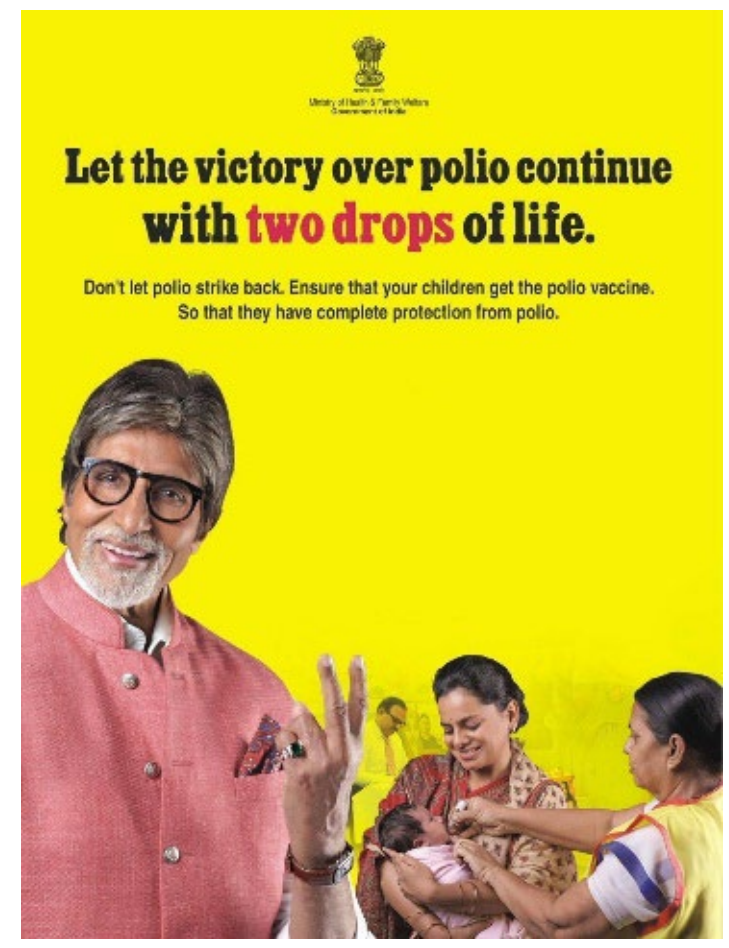

Figure 2 Amitabh Bachchan in the pulse polio campaign

Source 
Pulse polio campaign can be said as the Pioneer to the social campaigns, it was a great success campaign that was established and initiated by the government of India in the 1995- 96 for eradicating Polio in India by urging to vaccinate all children under the age of 5 years against the poliovirus. Amitabh Bachchan the very famous movie actor was chosen to convey the message, "DO BOOND ZINDAGI KI" and the message resonates in every Indian's head with a French-bearded baritone. A Remarkable change was noticed in the Polio ratio in Jaipur Rajasthan as the most of the convinced with the brand ambassador Amitabh Bachchan and his voice. Abrol 2017)

A same effort to ensure that Rajasthan too remains polio free, Union Health Minister Ghulam Nabi Azad inaugurated a pulse polio campaign of 2013 in Jaipur by administering polio drops to a seven-month-old child at the Jaipuria hospital. Tnn (2013)

The next in the list comes the very famous UNICEF campaign of November 2011 that was called the malnutrition Quit India or Kuposhan Bharat Chhodo, Aamir Khan was for which appointed as the National Ambassador, moreover after his successful television talk show (Satyamev Jayate) which discussed on the social issues of India people started recognizing him as a social leader who can bring about change. he very well educated the masses about how malnutrition is silent Destroyer and how it has impacted so harshly on the lives of children and even on pregnant women who feed their babies this campaign was seen and presented in over 18 languages all across the country and was when launched in Rajasthan even Opened the eyes of many to support the campaign various other campaigns were launched by the government like Anganwadi, Akshay Patra , Indira Gandhi Rasoi, for the masses. India News (2013)

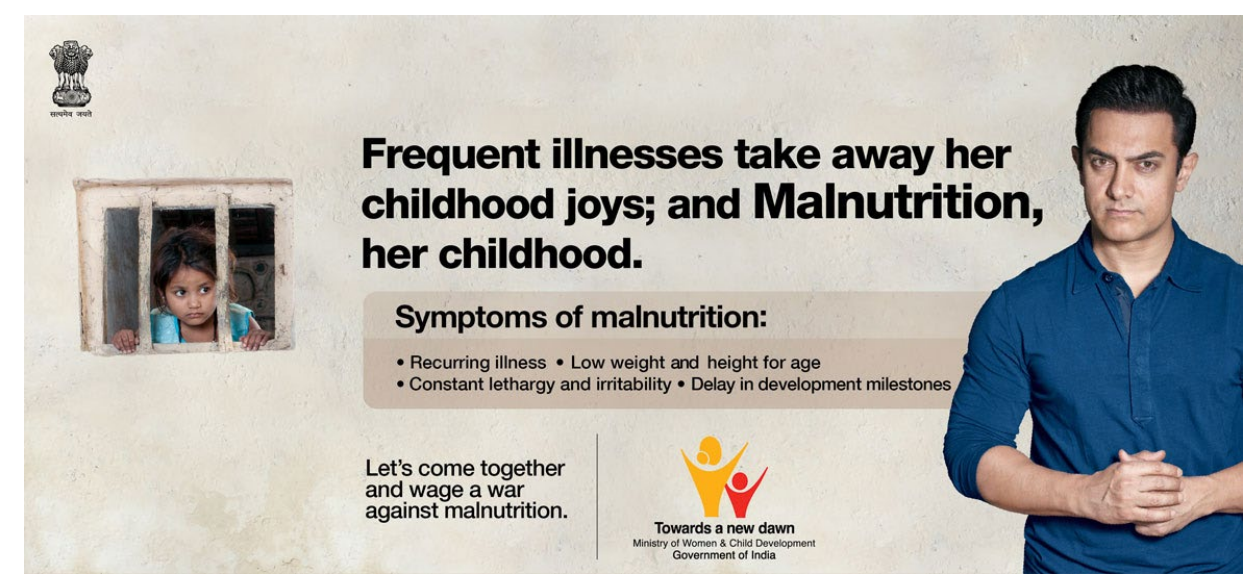

Figure 3 Amir Khan in the Malnutrition Campaign

Source

\section{OBJECTIVES OF THE RESEARCH}

- To identify weather celebrity endorsed campaigns are effective in grabbing viewers' attention.

- To examine the effect of celebrity endorsement in changing consumer habits 
- Has celebrity endorsement been successful in changing behaviour of people in Jaipur towards a positive social change?

\section{ENDORSEMENT IMPACT ON VIEWERS ATTENTION}

Viewers everyday come across thousands of advertisements which hamper companies in creating a unique position and receive attention from viewers. Celebrity endorsement has been applied in many of the ad campaign since many years and the strategy of celebrity endorsement or using a celebrity to endorse public awareness campaign has been steadily increasing since the last few years 1980 is a very good example for ads primary featuring TV and movie stars and today the celebrities have a domination over the market. The scenario of celebrity endorsement is not likely to change because the people being obsessed with the celebrities and their lifestyle, try copying them.

This emanates from the fact that media overload society with news and illustrations about celebrities, providing them with an entertainment function. To create the attention of people towards awareness message celebrity endorsement has always been useful. It has been noticed that the celebrities like Amir Khan or Amitabh Bachchan who have helped government to aware people about social issues leave an impact on people and can influence the public emotions perfectly. Customer behaviour Scholars and Advertising practitioners are devoting more attention to promotional endorsements and are regularly using to promote an endless social advertising.

A number of factors are important while the celebrities are used as the endorsers such as the personal qualities of the endorser reputation of the endorser likeability behaviour

For an advertisement or a campaign to be effective a strong relationship has to exist between the endorser and the celebrity whom he perceives a brand that is portraying it can be said that in today's time where advertisement plays a vital role in coordinating viewers' attention advertisement have become a very important tool for an organisation to induct all possible measures to influence motivate for inculcate a desire in the viewers mind to listen and watch the message through and effective advertising campaign. since 1980. Celebrities started to make part of the advertising business and were successful in creating awareness with their glitter and fame. It is very well observed that the government and social organisation endorse the celebrities in the social advertising to inform educate people in different areas of social interest throughout the world. By all the counts and data available. It is very well proven that the celebrity endorsement is a powerful tool but the main important factor is how you use it or do you utilise it correctly endorsing a celebrity not doubt ad up to the extra charm and impact on the social message it is necessary for the marketer to focus the celebrity who would appeal and would better connect with the target audience a celebrity who can easily convey people the message whether it is social or product or AD campaign. Kehvaria (2019)

\section{METHEODOLOGY}

To know the effectiveness of the celebrity endorsement in advertising in Jaipur a survey was conducted for which a questionnaire was prepared with seven close ended questions and a sample size of 90-100 people of the middle age group i.e.,30-

45 was considered and were distributed with the questionnaire and on the bases of 
the answers to the questionnaire the interpretation was done on pie charts making it more clear towards a conclusion.

\section{QUESTIONARE}

The following questionnaire consists of seven questions from the field of advertising to measure the effectiveness of celebrities in advertising. Please tick the option you think is correct for the following questions and return the questionnaire to the respected surveyor.

NAME:

AGE:

Q1. Do you think the attitude of the celebrity Endorsed in an advertisement affects consumers perception on social issues?

1) YES

2) $\mathrm{NO}$

- When the people were asked that do, they think the attitude of the celebrity Endorsed in an advertisement his attitude affects consumers perception on social issues the answer was $60 \%$ of them saying yes and $40 \%$ of them denied to it.

\section{Celebrity Affect consumers perseption on social issues}

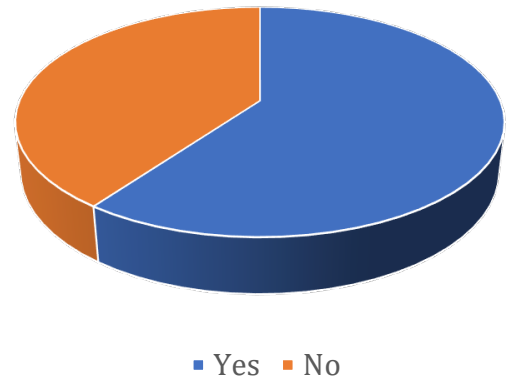

Q2. Do you think the celebrity endorsement affect the thoughts of the people intensions?

1) YES

2) $\mathrm{NO}$

- when they were asked that do, they think the celebrity endorsement affect the thoughts of people intention the answers were $70 \%$ agreed to this that people intension and thought are affected but 30\% refused. 


\section{celebrity endosment affecting thoughts of people intencion}

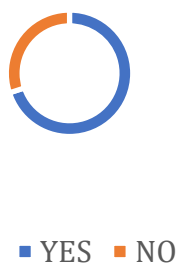

Q3. Who is the famous celebrity endorsed for the pulse polio campaign advertisement?

1) Amitabh Bachan

2) Vidya Balan

- When they were put up with a question that do, they know who the celebrity is endorsed for the pulse poli campaign they chose Amitabh Bachchan in majority with 60 percent but $40 \%$ still got with the wrong answer that was Vidya Balan.

\section{Celebrity Endorsed in Pulse Polio} Campaign

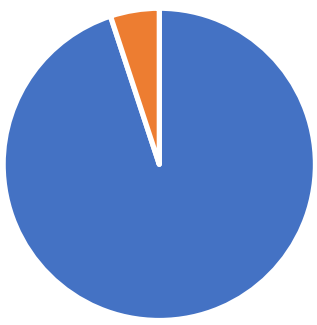

- Amitabh Bachan Vidya Balan

Q4. Do you think the celebrities endorsed in the ads actually follow the norms they teach?

1) Yes

2) No

- On asking them that do they think the celebrities endorsed in the ads actually follow the norms they teach the answers were not that shocking where $30 \%$ of them said yes and $70 \%$ said no they don't. 


\section{Celebrities folow the normes which they are preaching}

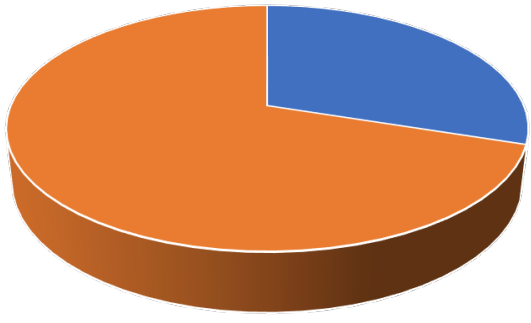

- Yes - No

Q5. Do you think the public get influenced by the celebrities in the advertisement?

1) Yes, to some extent

2) No Never

- Do you think the public get influenced by the celebrities in the advertisement was the next question put up before them and they came up with majority of them $80 \%$ saying yes to certain extent and the other part of 20 said no never?

\section{customers influenced by celebrities}

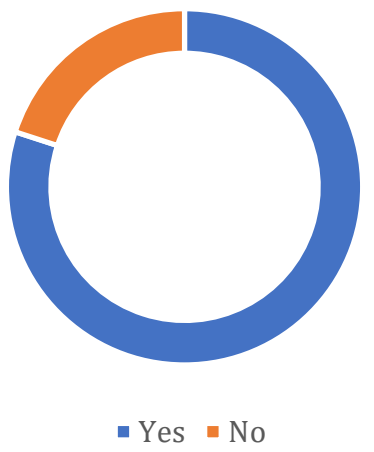

Q6. What according to you should be the criteria of choosing a celebrity for advertisement

1) How famous he is amongst the people

2) His image and the product image

- When they were questioned that what according to them should be the criteria for choosing a celebrity for a particular advertisement the answers were chosen to be more saying product category. and celebrities image i.e., 70 whereas the other 30 said how famous the celebrity is matters the most. 


\section{Criteria for choosing celebrities for advertising}

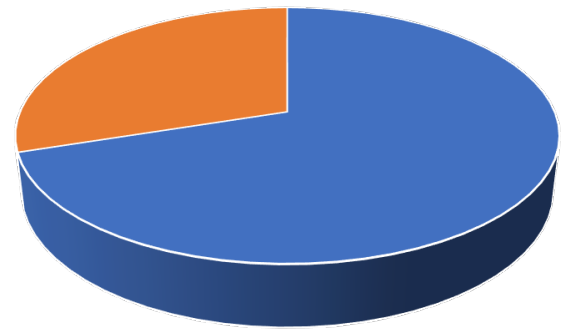

- Product category and Image - Popularity of Celebrity

Q7 What according to you are more influencing

1) celebrities in product Ads

2) celebrities in social ads

- When asked What according to them was more influencing Celebrities in social ads or celebrities in product ads the answer came to be as celebrities in social ads with $75 \%$ and 35 of them considered product ones more influencing.

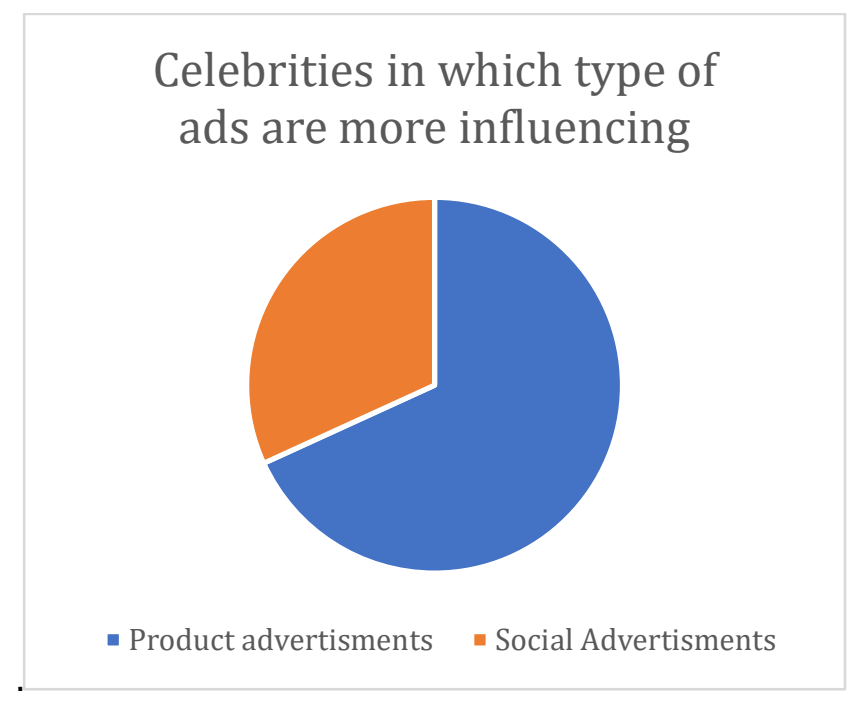

\section{CONCLUSION}

Advertising as we know is a very powerful and important communication tool today that helps in connecting with the audience and consumers, it creatively grabs the attention of its audience that is the target audience. It inducts all the possible measures to influence and create a need in the minds of people that further leads to buying of the product To make It more eye catchy and attention seeking the advertisements were updated with a new trend that introduced the celebrities in the advertisement the beginning of which is seen in the 1980'sIt was a very effective way where the glittery and sparkling life of the celebrities created a desire in the 
minds of people and they were successful in attracting majority of people with the passing of the time and development in technologies more and more featuring of celebrities was seen from being the endorsers of the product ads the celebrities were now made a part of the social ads where they informed the people about the issues prevailing in the society and the ways to deal with them say It the pulse polio campaign or the very famous song "Mile sur mera tumhara " featuring most of the celebrities in it ; celebrity endorsement has always grabbed eyes of many . the government and many social organisations have very well used celebrity endorsement to aware and educate the masses.

As the research has made us aware about the existing scenario stating that yes celebrity endorsement is an effective one that has been a very important part of advertising in Jaipur and can be said to as one that grabs attention of many through the campaigns like the pulse poli where in the people where influenced by the angry voice of Amitabh Bachchan and didn't want to see them angry makes us come up with a thought that celebrity endorsement is an effective tool and the main and powerful factor that makes it more powerful is how we use it Kehvaria (2019)

I further come up with a conclusion that Evidently, businesses and products who use celebrity endorsement as a tool to create awareness increase their marketability and create a better existence. Thus, attracting more people towards a positive behavioural change Celebrity endorsement is certainly one of the best strategies that companies should adopt when targeting big social issues. Celebrity endorsement is a tool that can apply to both small social issues that is state issues and large or big issues like the ones that involve the country or sometimes the global issues like the deforestation and water pollution etc. However, the type of stars may differ.

It is clear that endorsing a celebrity not just creates an extra charm and impact on people but also ads to it powerful existence amongst the other ads.

It should be looked into by the advertiser that the celebrity that is used is the one who's image is not different from that of the product and does not link with the product but should be one that helps people or viewer connect with the ad easily and convince them for a positive result.

\section{REFERENCES}

Abrol, S. (2017, October 24). India Today.

Celebrity Endorsement (2017, july 31).

Digital Globe (2017, November 2). The impact of Beti Bachao, Beti Padhao is right here, India now has 1020 females per 1000 males.

India News. (2013, March 23). Innlive network Wordpress.

Kehvaria, K. (2019). Celebrity Endorsement In Social Advertising. Journal of Advances Scholarly Researches In Allied Education.

Market Bliss (2016), 5 Reasons Why Celebrity Endorsements Work.

Martin Roll (2018). Branding and Celebrity Endorsements.

Ministry of Women and Child Développent (2017). Beti Bachao Beti Padhao.

Priya Kumar (2019). Freedom from Malnutrition (Kuposhan Mukt Bharat).

Ric Sweeney (2002).'Brand ambassadors' give your business a boost. 
Sela, R. (2016). Market Bliss Media.

Shibika Suresh (2013). The Malice Of Malnutrition In India : Do We See A Change Coming With 'Kuposhan Bharat Chhodo'.

Somya Abrol (2017), World Polio Day : How Amitabh Bachchan drove India to become polio-free.

The Economic Times, Politics (2018). Retrieved From The India Times.

Tnn. (2013). Azad Kicks Off Pulse Polio Campaign. The Times News

The economic times (2018). Swachh Bharat Mission has become a vibrant mass movement : Narendra Modi.

The economic times (2022).pm Narendra Modi launches swachh bharat campaign. 